Available online at GSC Online Press Directory

GSC Biological and Pharmaceutical Sciences

e-ISSN: 2581-3250, CODEN (USA): GBPSC2

Journal homepage: https://www.gsconlinepress.com/journals/gscbps

(RESEARCH ARTICLE)

\title{
Extraction and GC-MS analysis of the fatty acids in commonly consumed melon seed varieties in Nigeria
}

\author{
Olajuyigbe Aderonke Ariyike ${ }^{1}$, Amah Gogonte Hezekiah ${ }^{2}$, Adebawo Olugbenga Obajimi ${ }^{1,2}$ and Olajuyigbe \\ Olufunmiso Olusola ${ }^{3, *}$ \\ ${ }^{1}$ Department of Biochemistry, Olabisi Onabanjo University, Ago-Iwoye, Ogun State, Nigeria. \\ ${ }^{2}$ Department of Biochemistry, Benjamin Carson School of Medicine, Babcock University, Ilisan-Remo, Ogun State, Nigeria \\ ${ }^{3}$ Department of Microbiology, School of Science \& Technology, PMB 4005, Babcock University, Ilisan-Remo, Ogun State, \\ Nigeria.
}

Publication history: Received on 11 May 2019; revised on 24 June 2019; accepted on 27 June 2019

Article DOI: https://doi.org/10.30574/gscbps.2019.7.3.0086

\begin{abstract}
Egusi melon (Colocynthis citrullus lanatus) is a vegetable oil crop commonly grown in West Africa. In this study, four species of melon seeds, Cucumis melo, Citrullus lanatus, Citrullus vulgaris and Lagenaria siceraria, were analysed for fatty acid composition using Gas Chromatography Mass Spectrometry. The lipid profile showed that linoleic acid was the most predominant fatty acid in Lagenaria siceraria having the highest value (73.31\%), followed by Citrullus vulgaris (67.79\%) while Cucumis melo had 20.51\% and none was present in Citrullus lanatus. Lauric acid (6.44), palmitic acid (2.80\%), methyl esters of stearic acid (2.14\%), palmitic acid methyl ester (21.20\%), vaccenic acid (16.66\%) and myristic acid (49.91\%), which are saturated fatty acids, were found in Citrullus lanatus but were absent in the other melon species. In conclusion, this study showed that egusi Cucumis melo, Citrullus vulgaris and Lagenaria siceraria are rich sources of linoleic acid, an unsaturated fatty acid that is known to reduce the risk of cardiovascular diseases while Citrullus lanatus contain several saturated fatty acids which can increase the risk of cardiovascular diseases.
\end{abstract}

Keywords: Egusi; Citrullus lanatus; Linoleic acid; Unsaturated fatty acid

\section{Introduction}

Increasing population of the world has doubled the food demands and inundated the available land resources. Alongside other cheaper food alternatives which have been stressed and recognized by many stakeholders from national governments to international agencies like Food and Agricultural Organization (FAO), vegetable crops are considered cheap source of energy $[1,2]$. They are known rich sources of phytochemicals and nutrients such as carbohydrates, carotene, protein, vitamins, ascorbic acid, tannins and palpable concentration of trace minerals which are essential nutrients of life [3].

Cucurbitaceae, a vegetable family, is a large plant family consisting of nearly 100 genera and 750 species [4]. This plant family, known for its great genetic diversity and widespread adaptation across tropical and subtropical regions, arid deserts and temperate locations [5], are known for their high protein and oil content. Seeds of cucurbits are sources of oils and protein with about 50\% oil and up to 35\% protein [6]. Specifically, they are cultivated and consumed world over for these reasons. The family is made up of the following genera: Citrullus (water melon), Cucumeropsis (white melon), Cucumis (sweet melon), Cucurbita (pumpkin), Lagenaria (gourd), Luffa (luffa), Telfaria

\footnotetext{
${ }^{*}$ Corresponding author

E-mail address: funmijuyigbe12@yahoo.com
} 
(fluted pumpkin) and Trichosanthes (snake tomato) [7]. Each genus comprises many species and varieties which are widely grown in Nigeria.

Colocynthis citrullus lanatus ("Egusi" melon) is a creeping vegetable crop commonly grown in West Africa [8] and used as food source, medicinal, Engineering and cosmetics. Economically and socio-culturally, 'egusi' melon seeds are a good source of cash income, household food and gift to relatives [9] and fed-stock for biofuel [10, 11]. While it is a good source of amino acids and minerals [12], Girgis and Said [13] reported that its unsaturated fatty and linoleic acids suggested possible hypocholesterolemic effect. The seed kernels are found to be rich in unsaturated fatty acids, minerals and proteins [14]. In the South-western part of Nigeria, the kernels could be ground into paste and used in preparing local soup or fried in vegetable oil to produce a melon snack known as 'robo' or fermented into condiment called 'ogiri'. According to Ajibola [15], oil extracted from the seeds is used for cooking and for producing biscuits, margarines and soaps. The egusi fruit is not eaten because of its hard texture and bitterness. The colour of the seeds usually ranges between cream and yellow and can be of different sizes [16]. Sequel to its significant economic value as a food additive and lack of information on the quality of the essential oils from this plant, four species of melon seeds, Cucumis melo (local name - egusi wewe), Citrullus lanatus (local name - egusi bara), Citrullus vulgaris (local name egusi serewe) and Lagenaria siceraria (local name - egusi igba), were selected to investigate the fatty acid contents of these commonly consumed egusi seeds in Nigeria.

Citrullus colocyhthis lanatus (Thunb) originated from the western Kalahari region of Namibia and Botswana, where it could still be found in the wild in a diversity of forms together with other Citrullus species. Its cultivation became widespread in Mediterranean Africa, the Middle East and West Asia more than 3000 years ago [17]. In the Republic of Benin, 'egusi' species such as C. lanatus subsp. mucosospermus has a medicinal role. Its sliced young fruit could cure stomach aches while the seed coat in decoction with Eucalyptus (Eucalyptus camaldulensis Dehnh.) roots is a sedative for epilepsy. The roasted seeds, ground with salt and taken with warm water or porridge could prevent vomiting [10] and provide domestic remedy for urinary tract infection, hepatic congestion, intestinal worms and abnormal blood pressure [18]. Burkill [19] reported also that the seed of $C$. lanatus are used as vermifuge in Senegal while the juice is squeezed from pulp.

"Egusi" (Citrullus colocynthis L.) belongs to the species of the genus Citrullus of cucurbitaceae family, usually consisting of a large number of varieties that are generally known as melons [20]. Typically, C. citrullus has been confused with Citrullus colocynthis. Consequently, the egusi melon has sometimes been considered a common name for $C$. colocynthis [21]. However, Omotoye [22] indicated that "egusi Bara" is specifically called Citrullus colocynthis but Badifu [23] referred to it as Citrullus lanatus. 'Bara', also known as "egusi papa", has large brown seeds with thick black edges thickened towards the apex, about $16 \times 9.5 \mathrm{~mm}$ and is common in the northern and western parts of Nigeria [24]. The plant has become naturalised in many drier parts of West Africa [25].

Egusi 'sewere' or brown-seeded melon, also known as Citrullus vulgaris Schrad [23], is a trailing herbaceous and annual vine with woody rootstocks. While it is grown widely in the tropic and also in the temperate regions of the world where it requires a lot of heat [26], its cultivation is simple and the fruits can produce up to 200 - 300 seeds per gourd [27]. It is a monoecius plant grown from seeds and creeps with plant population density of $20000-40000$ plants per hectare [26]. It is estimated that one plant can produce up to 10 gourds [28].

Cucumis melo var. Agrestis Schrad also known in Yoruba as Baara-ekate or egusi wewe [29] is an annual climber growing up to $1.5 \mathrm{~m}$. Stem is generally covered with rough hairs. Leaves are triangular, ovate, 3-5-lobed, and rough with rigid hairs. Leaf stalk is $1-6 \mathrm{~cm}$ long. The fruits have a bitter flavour and can be used as a cooling light cleanser or moisturizer for the skin and also as first-aid treatment for burns and abrasions [19]. The seeds are used as a vermifuge in Senegal and juice squeezed from pulp roasted in fire-ash is drunk in Southern Nigeria as an anthelmintic agent [30]. Their strengthening and diuretic properties are recognized in India while their beneficial uses in acute cystitis and capacity to lower the blood pressure have also been recorded [31].

Lagenaria siceraria (Mol.) Standley, also known as bottle gourd, egusi igba and/or calabash gourd, is an annual plant with alternate leaves and climbing or creeping on the soil. Fruits are large and vary, up to $800 \times 1200 \mathrm{~mm}$, subglobose to cylindrical, flask-shaped or globose with a constriction above the middle, fleshy, densely hairy to ultimately glabrous, indehiscent, green, maturing yellowish or pale brown. The pulp dries out completely on ripening, leaving a thick, hard, hollow shell with almost nothing inside except the seeds.

Although several studies have reported predominantly high linoleic acid content in egusi melon seed oils [32, 33], specific species of "egusi" used in these studies are rarely mentioned. Since there is a dearth of information on the chemical composition of the oil from these species of "egusi" and there is a need to associate their nutritive values and 
nutritional composition with their economic importance, this study was designed to identify and quantify the essential the fatty acid compositions of four different species of selected "egusi" melon seeds.

\section{Materials and methods}

Four species of unshelled egusi melon seeds were purchased from different markets in South-Western part of Nigeria. The species were Citrullus lanatus (egusi bara), Citrullus vulgaris (egusi sewere), Lagenaria siseraria (egusi igba) and Cucumis melo (egusi wewe). The melon seeds were shelled, pulverized and stored in labeled air-tight containers prior analysis.

\subsection{Oil Extraction}

One hundred gram of each of the melon seeds was mashed into smaller pieces and placed inside a thimble made from thick filter paper. This was then loaded into the main chamber of the Soxhlet extractor. The extraction solvent used was petroleum ether. The solvent was heated to reflux at $100{ }^{\circ} \mathrm{C}$ for $5-10 \mathrm{~h}$. After the extraction, the samples were left under fume hood for $1 \mathrm{~h}$ to make sure all the petroleum ether in the crude oil was completely dried off.

\subsection{Gas Chromatography-Mass Spectrometric (GC-MS) analyses}

The GC-MS analysis was carried out at the University of Lagos, Akoka, Lagos state, Nigeria. The GC-MS analysis were carried out using Gas chromatograph interfaced to a mass spectrometer GC-MS-QP 2010 Plus Shimadzu system (GCMS) employing the following conditions: Column Elite-1 fused silica capillary column $(30 \mathrm{~m} \times 0.25 \mathrm{~mm} 1 \mathrm{D} \times \mu \mathrm{df}$, composed of $100 \%$ dimethyl polysiloxane). For GC-MS detection, an electron ionization system with ionization energy of $70 \mathrm{eV}$ was used. Helium gas (99.999\%) was used as the carrier gas at constant flow rate of $1 \mathrm{ml} / \mathrm{min}$ and an injection volume of $2 \mu \mathrm{l}$ was employed (Split ratio of $10: 1$ ) injector temperature $-250{ }^{\circ} \mathrm{C}$; ion-source temperature $280{ }^{\circ} \mathrm{C}$. The oven temperature was programmed from $110^{\circ} \mathrm{C}$ (Isothermal for $2 \mathrm{~min}$ ) with an increase of $10^{\circ} \mathrm{C} / \mathrm{min}$ to $200^{\circ} \mathrm{C}$ then 5 ${ }^{\circ} \mathrm{C} / \mathrm{min}$ to $280^{\circ} \mathrm{C} / \mathrm{min}$, ending with a $9 \mathrm{~min}$ isothermal at $280^{\circ} \mathrm{C}$. Mass spectra were taken at $70 \mathrm{eV}$; a scan interval of $0.5 \mathrm{~s}$ and fragments from 40 to $550 \mathrm{Da}$. Total GC running time was $36 \mathrm{~min}$. The relative percentage amount of each component was calculated by comparing its average peak area to the total areas. Software adopted to handle mass spectra and chromatogram was a turbomass.

\subsection{Identification of Components}

The mass spectrum of GC-MS was interpreted using the database of National Institute of Standard and Technology (NIST) having more than 62,000 patterns by comparing the mass spectrum of the unknown components with those of the known elements stored in the NIST library. The name, molecular weight and chemical structure of the test material were ascertained.

\section{Results}

From Figure 1 showing the chromatogram of Citrullus vulgaris, 14 different compounds were identified by the GC-MS analysis as shown in Table 1 . Of the different chemical compounds identified, the saturated fatty acid present in egusi sample included palmitic acid (2.01\%), the saturated fatty acid derivatives included palmitic acid ethyl ester (2.89\%) and pentadecanoic acid -14-methyl-, methyl ester $(0.40 \%)$. The most abundant unsaturated fatty acids were linoleic acid $(67.79 \%)$ and ethyl Oleate $(4.35 \%)$. The percentage of unsaturated (88.09\%) was higher than that of saturated $(5.72 \%)$ fatty acids as shown in Table 2. 
Olajuyigbe et al. / GSC Biological and Pharmaceutical Sciences 2019, 07(03), 077-092

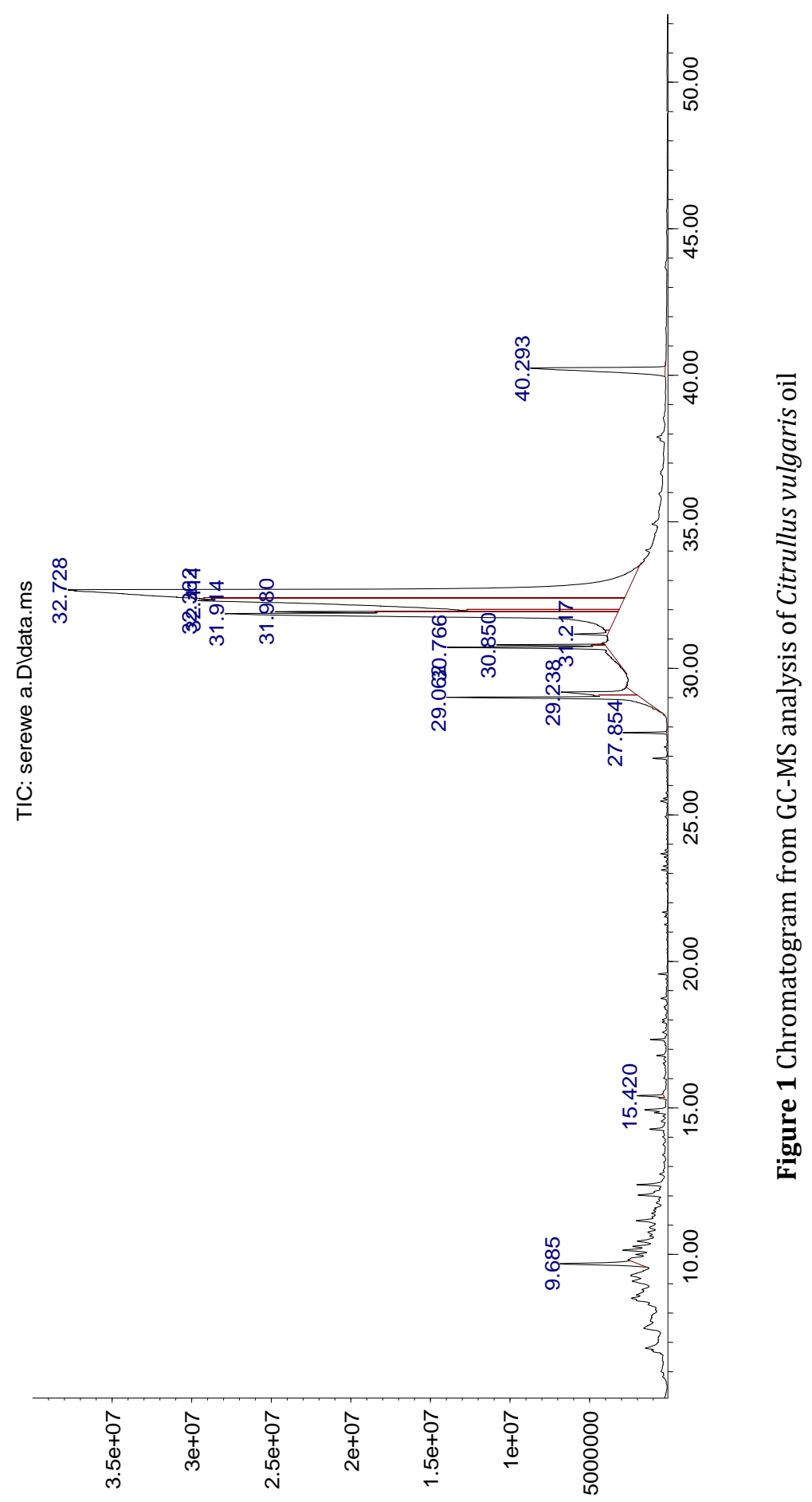


Olajuyigbe et al. / GSC Biological and Pharmaceutical Sciences 2019, 07(03), 077-092

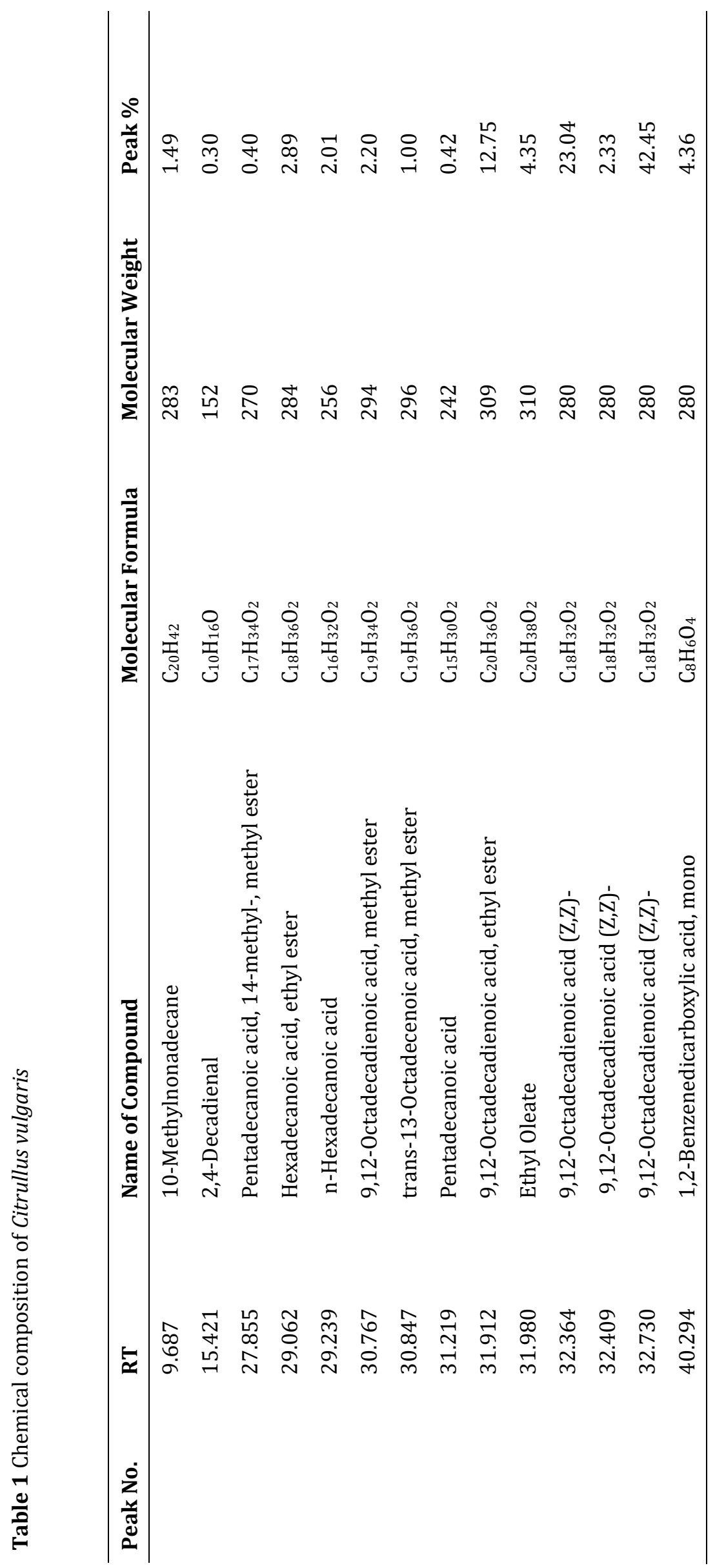


From Figure 2 showing the chromatogram of the GC-MS analysis of Lagenaria siceraria, 21 chemical compounds were identified as shown in Table 3. Of these chemical compounds, two fatty acids including Hexadecanoic acid ethyl ester and 9,12-Octadecadienoic acid were identified. 9,12-Octadecadienoic acid was the highest quantity of fatty acid in Lagenaria siceraria as shown in Table 4.

From Figure 3 showing the mass spectra of the compounds present in Cucumis melo, 24 compounds were identified to be present in Cucumis melo as shown in Table 5. Of these compounds, the predominant fatty acid is Linoleic acid $(15.17 \%)$ and its esters which are essential fatty acids. The Cucumis melo was found to be very low in palmitic acid $(1.09 \%)$, which is a saturated fatty acid. Thus, the unsaturated fatty acid $(22.90 \%)$ was higher than the saturated fatty acid (1.65\%) in this species of egusi as shown in Table 6 while the organic compounds in Cucumis melo is presented in Table 7. In addition to its fatty acid, Cucumis melo has a number of volatile organic compounds contributing to the aroma of the melon seed. The volatile compounds include hemelitol, hemimellitene, o-cymene, undecane, durene, dodecane and tetradecane as shown in Table 7.

In Citrullus lanatus, six saturated fatty acids and two organic compounds were found to be present as shown in Table 8. Of these saturated fatty acids, methyl tetradecanoate (41.91\%) was the highest quantitatively. This acid was followed by methyl esters of hexadecanoic acid (21.20\%) and 11-Octadecenoic acid (16.66\%). While other fatty acids found in Citrullus lanatus were present in varied quantity, n-Hexadecanoic acid (2.80\%) was the least saturated fatty acid in terms of quantity. The identified organic compounds were Bis-(2-ethylhexyl)-phthalate (6.58\%) and 1Octadecene $(2.27 \%)$ present in varied quantity.

Table 9 shows the fatty acid content of Citrullus lanatus. Six saturated fatty acids were identified. The predominant saturated fatty acid was myristic acid methyl ester (49.91\%) while palmitic acid methyl ester was $21.20 \%$. Other fatty acids were vaccenic acid methyl ester (16.66\%), lauric acid (6.44\%), stearic acid methyl ester (2.14\%) and palmitic acid $(2.80 \%)$.

As shown in Table 10, comparatively, Lagenaria siceraria has the highest percentage composition of linoleic acid (73.31\%), followed by Citrullus vulgaris (67.79\%), Cucumis melo has the lowest composition of linoleic acid (20.51\%) while Citrullus lanatus has none. Linoleic acid ester was present in Cucumis melo (4.41\%) and Citrullus vulgaris (12.75\%) but not in Lagenaria siceraria and Citrullus lanatus. Lagenaria siceraria is composed of 16.86\% of 2,4decadienal, Citrullus vulgaris contained $0.30 \%$ of the compound and it was not recorded in Cucumis melo and Citrullus lanatus. While the palmitic acid ethyl ester which is hexadecanoic acid ethyl ester was very low in Cucumis melo (1.09\%), Citrullus vulgaris (2.89\%) and Lagenaria siceraria (0.63\%), Citrullus lanatus had none. Quantitatively, 1, 2Benzenedicarboxylic acid was higher in Cucumis melo (15.18\%), Citrullus vulgaris (4.35\%) and Lagenaria siceraria $(2.13 \%)$ respectively with none present in Citrullus lanatus. Palmitic acid i.e n-Hexadecanoic acid was present in Citrullus vulgaris $(2.01 \%)$ and Citrullus lanatus (2.80\%) but was not found in Cucumis melo and Lagenaria siceraria. Hexadecanoic acid methyl ester (21.20\%), methyl stearate (2.14\%), methyl tetradecanoate (49.91\%), dodecanoic acid (6.44\%), were, however, present only in Citrullus lanatus.

Table 2 Fatty Acid content of Citrullus vulgaris

\begin{tabular}{lllll}
\hline s/n & Fatty acid & \% Peak & Common name & Type of fatty acid \\
\hline 1. & Pentadecanoic acid, 14-methyl-, methyl ester & 0.40 & Palmitic acid methyl ester & Saturated \\
2. & Hexadecanoic acid, ethyl ester & 2.89 & Palmitic acid ethyl ester & Saturated \\
3. & n-Hexadecanoic acid & 2.01 & Palmitic acid & Saturated \\
4. & $9,12-$-Octadecadienoic acid, methyl ester & 2.20 & Linoleic acid methyl ester & Unsaturated \\
5. & trans-13-Octadecenoic acid, methyl ester & 1.00 & Linoleic acid ester & Unsaturated \\
6. & Pentadecanoic acid & 0.42 & Pentadecacylic acid & Saturated \\
7. & $9,12-$-Octadecadienoic acid, ethyl ester & 12.75 & Linoleic acid ester & Unsaturated \\
8. & Ethyl Oleate & 4.35 & Oleic acid ethyl ester & Unsaturated \\
9. & $9,12-$-Octadecadienoic acid & 67.79 & Linoleic acid & Unsaturated \\
\hline
\end{tabular}


Olajuyigbe et al. / GSC Biological and Pharmaceutical Sciences 2019, 07(03), 077-092

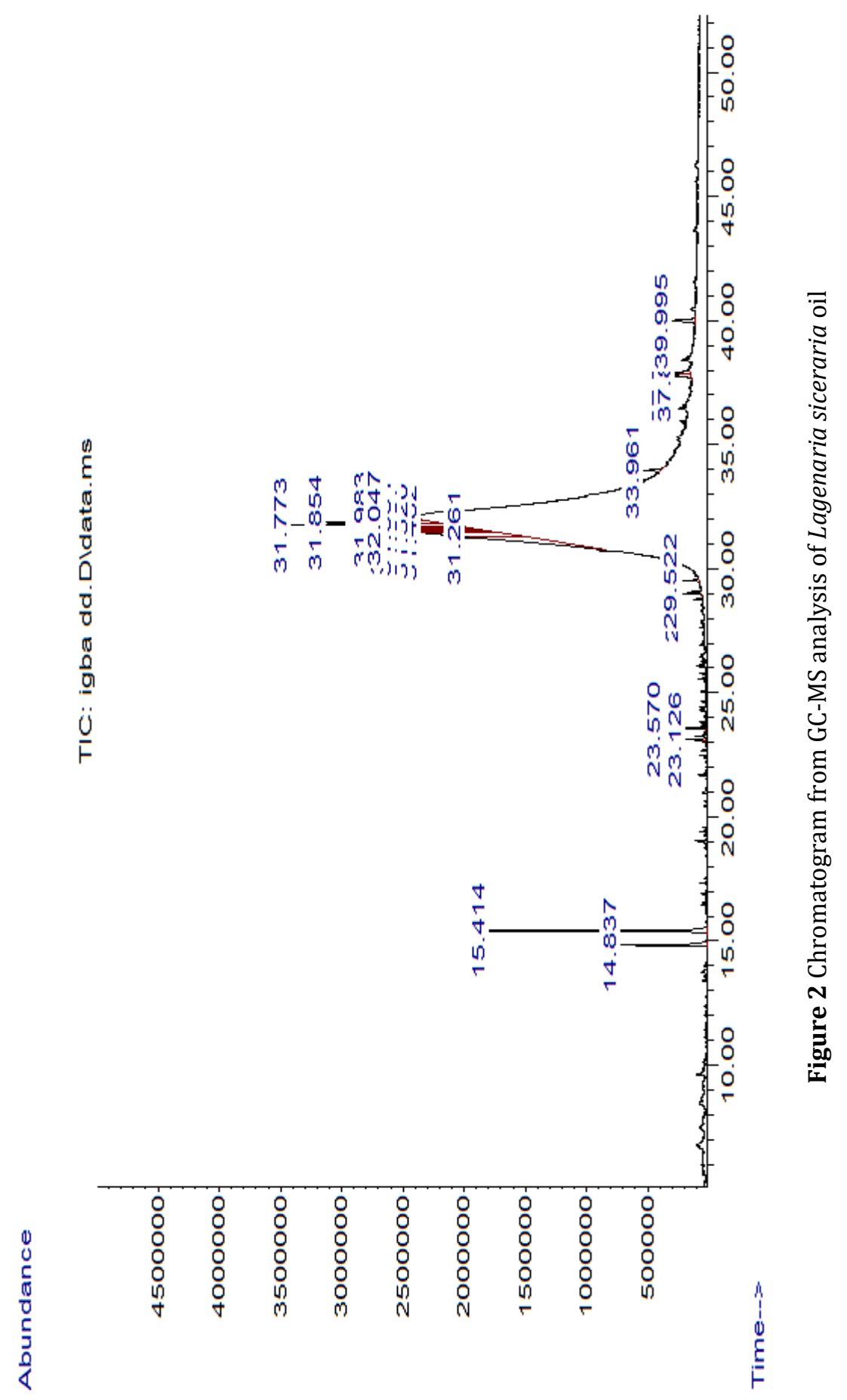


Table 3 Chemical composition of Lagenaria siceraria

\begin{tabular}{|c|c|c|c|c|c|}
\hline Peak No. & RT & Name of Compound & $\begin{array}{l}\text { Molecular } \\
\text { Formula }\end{array}$ & $\begin{array}{l}\text { Molecular } \\
\text { Weight }\end{array}$ & Peak \% \\
\hline 1. & 14.837 & 2,4-Decadienal (E, E) & $\mathrm{C}_{10} \mathrm{H}_{16} \mathrm{O}$ & 152 & 5.58 \\
\hline 2. & 15.415 & 2,4-Decadienal (E, E) & $\mathrm{C}_{10} \mathrm{H}_{16} \mathrm{O}$ & 152 & 12.28 \\
\hline 3. & 23.128 & Cyclodecene & $\mathrm{C}_{19} \mathrm{H}_{34} \mathrm{O}_{2}$ & 294 & 0.97 \\
\hline 4. & 23.569 & Cyclodecene & $\mathrm{C}_{19} \mathrm{H}_{34} \mathrm{O}_{2}$ & 294 & 1.64 \\
\hline 5. & 29.005 & Hexadecanoic acid, ethyl ester & $\mathrm{C}_{18} \mathrm{H}_{36} \mathrm{O}_{2}$ & 284 & 0.63 \\
\hline 6. & 29.520 & $\begin{array}{l}\text { i-Propyl 14-methyl- } \\
\text { pentadecanoate }\end{array}$ & $\mathrm{C}_{16} \mathrm{H}_{32} \mathrm{O}_{2}$ & 256 & 0.82 \\
\hline 7. & 31.259 & 9,12-Octadecadienoic acid (Z,Z)- & $\mathrm{C}_{18} \mathrm{H}_{32} \mathrm{O}_{2}$ & 280 & 13.59 \\
\hline 8. & 31.465 & 9,12-Octadecadienoic acid (Z,Z)- & $\mathrm{C}_{18} \mathrm{H}_{32} \mathrm{O}_{2}$ & 280 & 13.49 \\
\hline 9. & 31.522 & 9,12-Octadecadienoic acid (Z,Z)- & $\mathrm{C}_{18} \mathrm{H}_{32} \mathrm{O}_{2}$ & 280 & 4.45 \\
\hline 10. & 31.585 & 9,12-Octadecadienoic acid (Z,Z)- & $\mathrm{C}_{18} \mathrm{H}_{32} \mathrm{O}_{2}$ & 280 & 4.78 \\
\hline 11. & 31.637 & 9,12-Octadecadienoic acid (Z,Z)- & $\mathrm{C}_{18} \mathrm{H}_{32} \mathrm{O}_{2}$ & 280 & 3.93 \\
\hline 12. & 31.688 & 9,12-Octadecadienoic acid (Z,Z)- & $\mathrm{C}_{18} \mathrm{H}_{32} \mathrm{O}_{2}$ & 280 & 3.76 \\
\hline 13. & 31.774 & 9,12-Octadecadienoic acid (Z,Z)- & $\mathrm{C}_{18} \mathrm{H}_{32} \mathrm{O}_{2}$ & 280 & 12.22 \\
\hline 14 & 31.857 & 9,12-Octadecadienoic acid (Z,Z)- & $\mathrm{C}_{18} \mathrm{H}_{32} \mathrm{O}_{2}$ & 280 & 9.91 \\
\hline 15. & 31.940 & 9,12-Octadecadienoic acid (Z,Z)- & $\mathrm{C}_{18} \mathrm{H}_{32} \mathrm{O}_{2}$ & 280 & 2.06 \\
\hline 16. & 31.986 & 9,12-Octadecadienoic acid (Z,Z)- & $\mathrm{C}_{18} \mathrm{H}_{32} \mathrm{O}_{2}$ & 280 & 2.59 \\
\hline 17 & 32.049 & 9,12-Octadecadienoic acid (Z,Z)- & $\mathrm{C}_{18} \mathrm{H}_{32} \mathrm{O}_{2}$ & 280 & 0.75 \\
\hline 18. & 33.960 & cis-Vaccenic acid & $\mathrm{C}_{18} \mathrm{H}_{34} \mathrm{O}_{2}$ & 282 & 1.07 \\
\hline 19. & 37.771 & 9,12-Octadecadienoic acid (Z,Z)- & $\mathrm{C}_{18} \mathrm{H}_{32} \mathrm{O}_{2}$ & 280 & 1.78 \\
\hline 20. & 37.879 & 9,17-Octadecadienal, (Z)- & $\mathrm{C}_{18} \mathrm{H}_{32} \mathrm{O}$ & 264 & 1.57 \\
\hline 21. & 39.996 & $\begin{array}{l}\text { 1,2-Benzenedicarboxylic acid, } \\
\text { mono }\end{array}$ & $\mathrm{C}_{8} \mathrm{H}_{6} \mathrm{O}_{4}$ & 166 & 2.13 \\
\hline
\end{tabular}

Table 4 Fatty acid composition of Lagenaria siceraria

\begin{tabular}{lllll}
\hline & Fatty acid & \% composition & Common name & Type of fatty acid \\
\hline 1. & Hexadecanoic acid, ethyl ester & 0.63 & Palmitic acid ester & Saturated \\
2. & 9,12 -Octadecadienoic acid & 73.31 & Linoleic acid & Unsaturated \\
\hline
\end{tabular}


Olajuyigbe et al. / GSC Biological and Pharmaceutical Sciences 2019, 07(03), 077-092

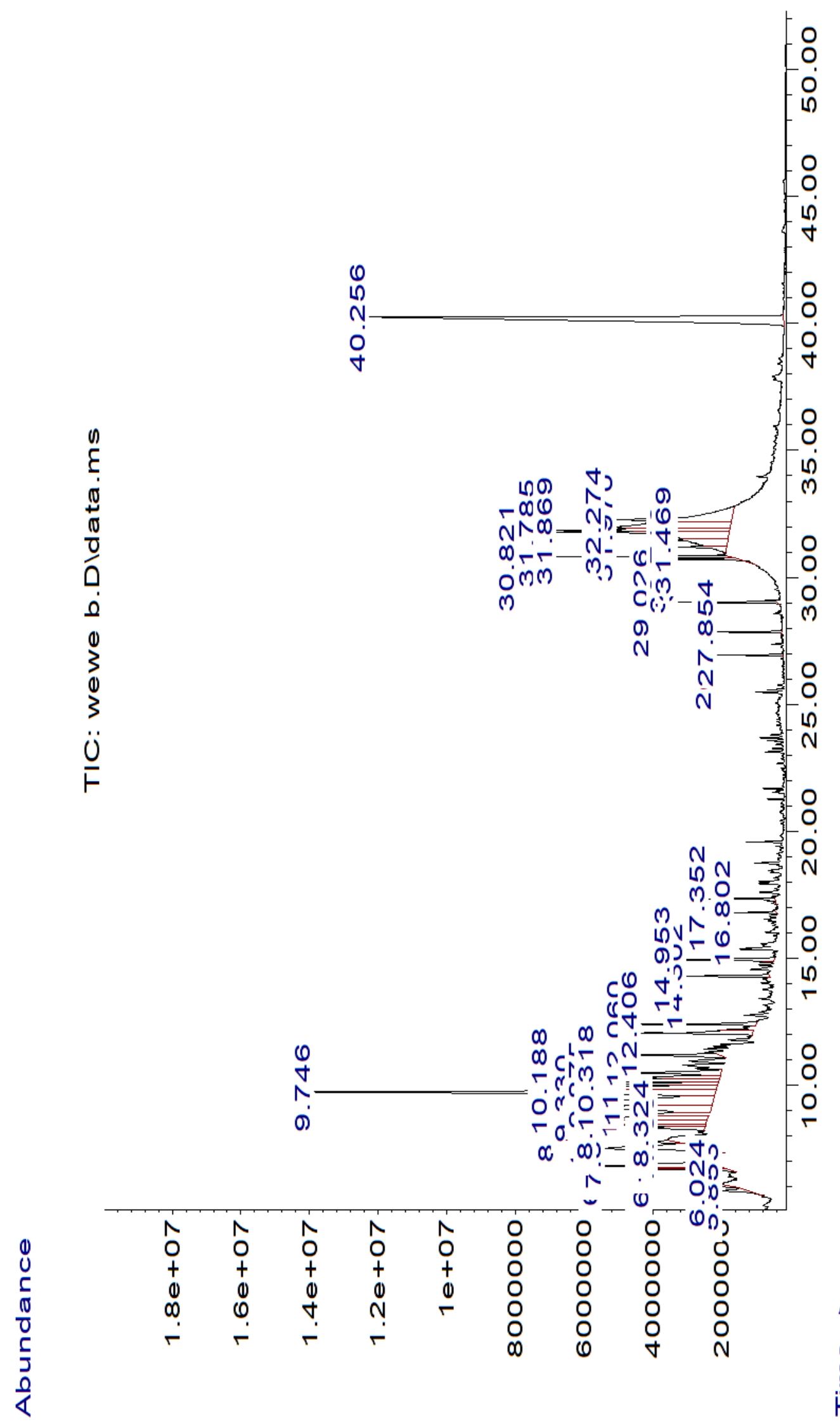




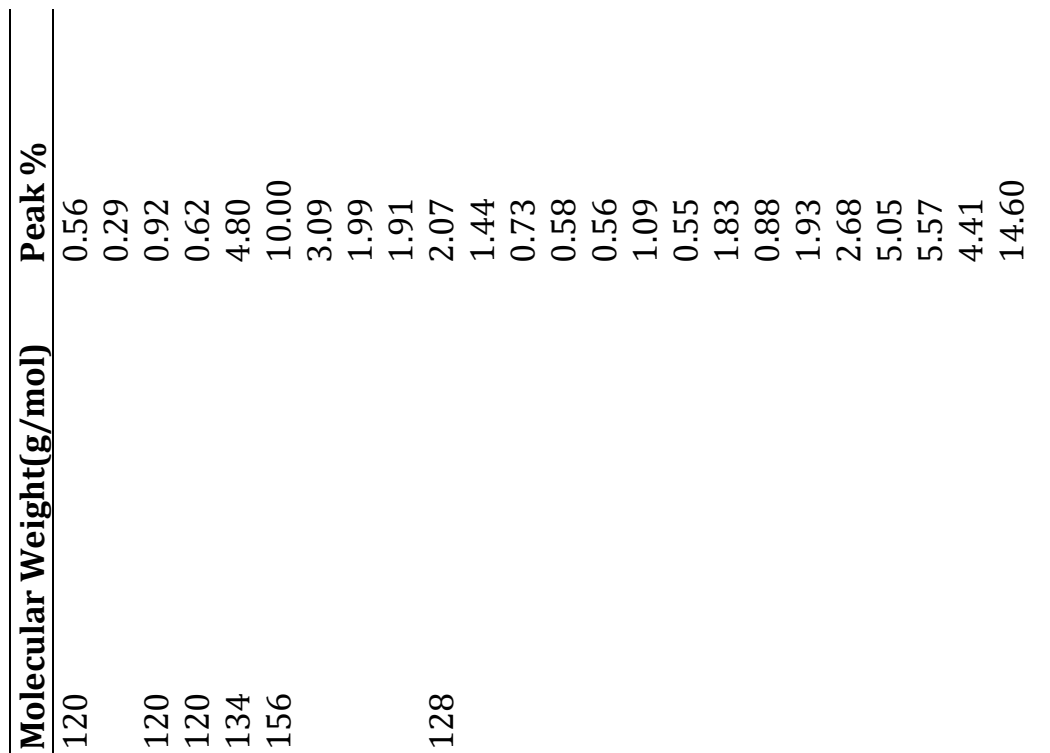

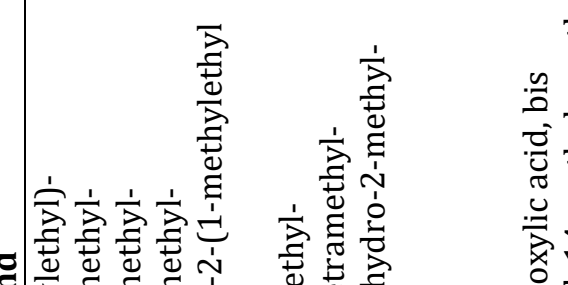

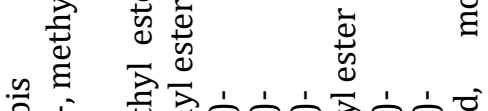

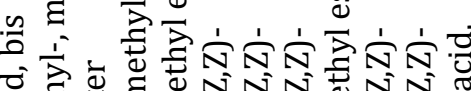

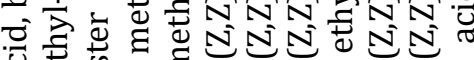

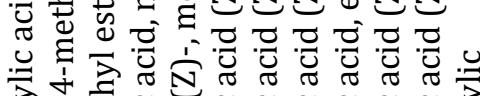

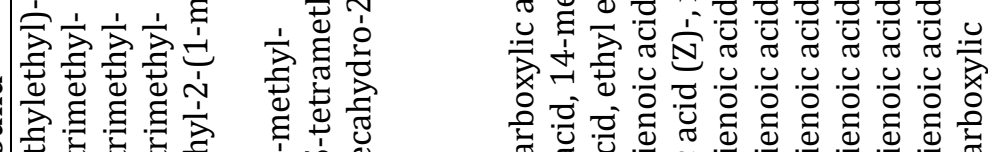

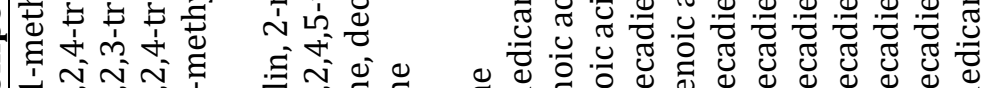

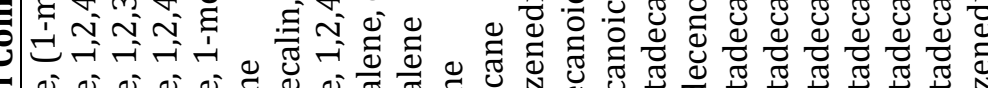
它

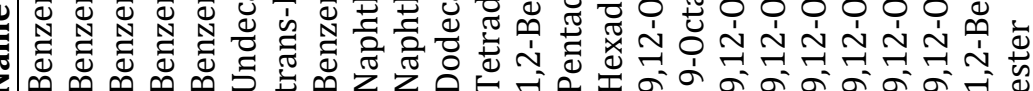

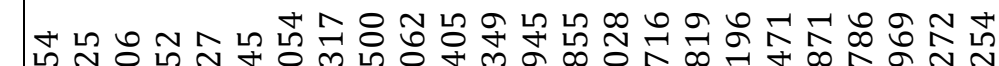
脊 
Table 7 Organic compounds present in Cucumis melo

\begin{tabular}{llll}
\hline & Chemical compound & Common names & Nature of compound \\
\hline 1. & Benzene-1,2,4-trimethyl & Hemelitol & Organic compound \\
2. & Benzene-1,2,3-trimethyl & Hemimellitene & Organic compound \\
3. & Benzene-1-methyl-2- & o-cymene & Organic compound \\
4. & Undecane & Undecane & Alkane hydrocarbon \\
5. & Trans-Decalin-2-methyl & - & Organic compound \\
6. & Naphthalene Benzene-1,2,4,5-tetramethyl & Durene & Organic compound \\
7. & Dodecane & Dodecane & Alkane hydrocarbon \\
8. & Tetradecane & Tetradecane & Alkane hydrocarbon \\
9. & Naphthalene, decahydro-2- & - & Organic compound \\
10 & 1,2-Benzenedicarboxylic acid, mono(2-ethylhexyl) & Ethylhexyl pthalate & Organic compound \\
& ester & & \\
\hline
\end{tabular}

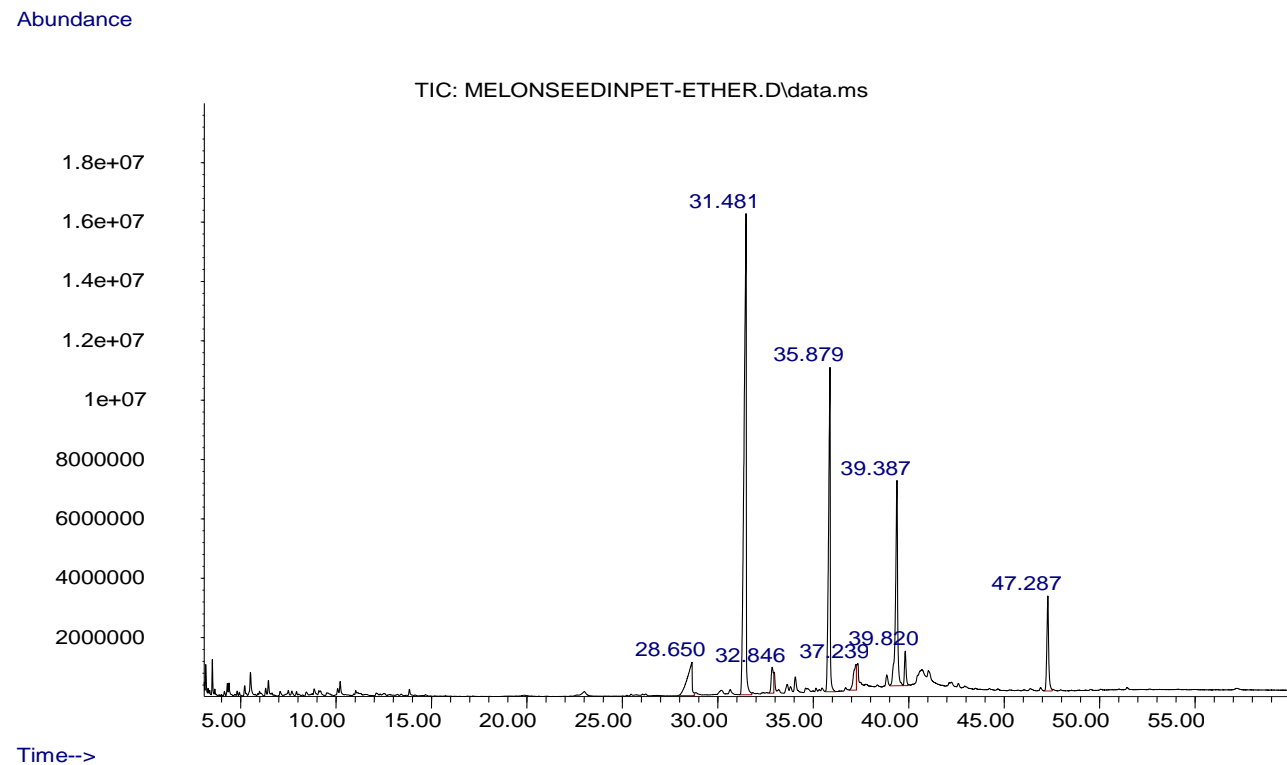

Figure 4 Chromatogram from GC-MS analysis of Citrullus lanatus oil

Table 8 Chemical composition of Citrullus lanatus oil

\begin{tabular}{llllll}
\hline $\begin{array}{l}\text { Peak } \\
\text { No. }\end{array}$ & RT & Name of Compound & $\begin{array}{l}\text { Molecular } \\
\text { Formula }\end{array}$ & $\begin{array}{l}\text { Molecular } \\
\text { Weight }(\mathrm{g} / \mathrm{mol})\end{array}$ & Peak \% \\
\hline 1. & 28.650 & Dodecanoic acid & $\mathrm{C}_{12} \mathrm{H}_{24} \mathrm{O}_{2}$ & 200 & 6.44 \\
2. & 31.481 & Methyl tetradecanoate & $\mathrm{C}_{15} \mathrm{H}_{30} \mathrm{O}_{2}$ & 242 & 41.91 \\
3. & 32.846 & 1-Octadecene & $\mathrm{C}_{18} \mathrm{H}_{36}$ & 252 & 2.27 \\
4. & 35.879 & Hexadecanoic acid, methyl ester & $\mathrm{C}_{18} \mathrm{H}_{36} \mathrm{O}_{2}$ & 284 & 21.20 \\
5. & 37.239 & n-Hexadecanoic acid & $\mathrm{C}_{16} \mathrm{H}_{32} \mathrm{O}_{2}$ & 256 & 2.80 \\
6. & 39.387 & 11-Octadecenoic acid, methyl ester & $\mathrm{C}_{19} \mathrm{H}_{36} \mathrm{O}_{2}$ & 296.49 & 16.66 \\
7. & 39.820 & Methyl stearate & $\mathrm{C}_{19} \mathrm{H}_{38} \mathrm{O}_{2}$ & 296 & 2.14 \\
8. & 47.287 & Bis(2-ethylhexyl) phthalate & $\mathrm{C}_{24} \mathrm{H}_{38} \mathrm{O}_{4}$ & 390.6 & 6.58 \\
\hline
\end{tabular}



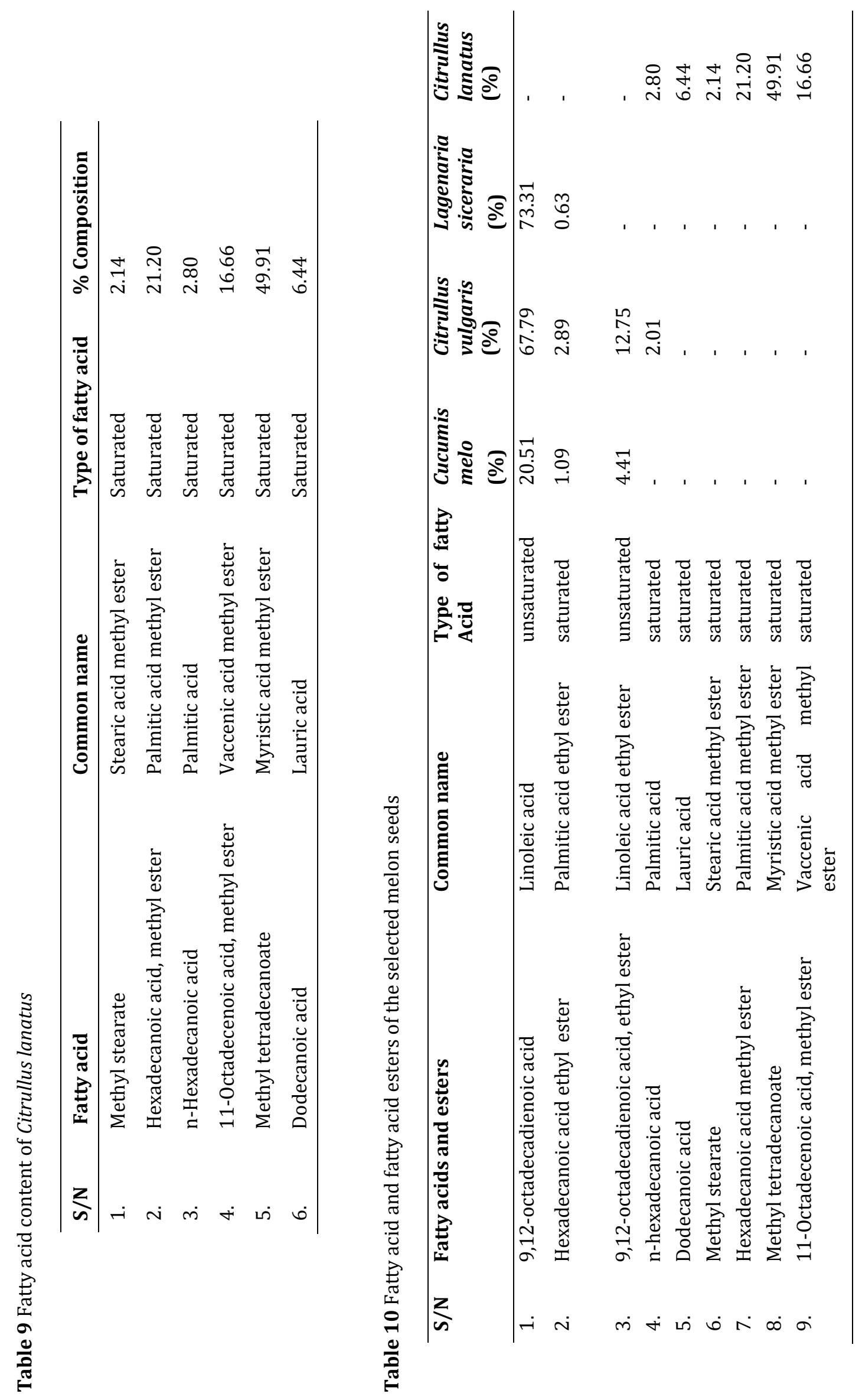


\section{Discussion}

Vegetable oils have an important functional and sensory role in food products because of their fatty acids composition and the fat-soluble vitamins (A, D, E, and K). They are also sources of energy and essential fatty acids like linoleic and linolenic that are responsible for growth and the health of organisms [34]. Oil that contains fatty acids with short chain have lower melting point and are more soluble in water. Whereas, the oils that contain fatty acids with longer chain have higher melting points. Unsaturated acids will have a lower melting point compared to saturated fatty acids of similar chain length [35]. From the gas chromatography mass spectrometry result, Lagenaria siceraria has the highest percentage composition of linoleic acid (73.31\%), followed by Citrullus vulgaris (67.79\%) and Cucumis melo having the lowest composition of linoleic acid (20.51\%) while none was found in Citrullus lanatus. The linoleic acid value for Lagenaria siceraria (73.31\%) was higher than was obtained from melon seeds by Olaofe et al. [36] which was (67.7\%) but similar to $67.79 \%$ obtained for Citrullus vulgaris.

Linoleic acid, found in the lipids of cell membranes and abundant in many vegetable oils, poppy seed, safflower, sunflower and corn oils [37], is a polyunsaturated fatty acid used in the biosynthesis of arachidonic acid sitting at the head of the "arachidonic acid cascade" that controls a wide array of bodily functions especially those involving inflammation and the central nervous system [38]. In fatty acid metabolism, linoleic acid is metabolized to gammalinoleic acid and subsequently arachidonic acid (AA). A-linoleic acid is metabolized to both eicosapentaenoic acid and docosahexaenoic acid [39]. Eicosapentaenoic acid and docosahexaenoic acid are metabolized by the body into eicosanoids and ultimately become the prostaglandins which affect such varied functions as blood clotting, inflammation response, and immunoregulation [40].

With respect to modern diets, the amount of linoleic acid consumed has increased exceptionally in the past 100 to 150 years [39]. While linoleic acid has the ability to reduce the risk of cardiovascular heart diseases by lowering blood cholesterol levels, it is used to reduce mastalgia (menstrual pain) and oleic acid could act as an anti-allergic agent [41]. That Linoleic acid ester was present in Cucumis melo (4.41\%) and Citrullus vulgaris (12.75\%) but not in Lagenaria siceraria and Citrullus lanatus indicated that more of Cucumis melo and Citrullus vulgaris should be consumed. As physiological conditions can inhibit the conversion process of linoleic acid and $\alpha$-linoleic acid to the other essential Omega-3 and Omega- 6 fatty acids, Cucumis melo and Citrullus vulgaris could be alternative sources of linoleic acid which is one of the three essential fatty acids [42].

Although Lagenaria siceraria is composed of $16.86 \%$ of 2,4-decadienal, Citrullus vulgaris contained $0.30 \%$ of this compound not found in Cucumis melo. 2, 4-decadienal is an aromatic substance with deep fat flavour. While 2,4decadienal is generated from polyunsaturated fatty acids by the action of plant lipoxygenases and used as a synthetic flavoring and fragrance material, its presence in higher percentage in Lagenaria siceraria, not commonly consumed, may boost its economic value and enhance its use as a food condiment over and above other types of melons. Shi and Ho [43] and Mottram [44] indicated that 2,4-decadienal is responsible for the inviting aroma of deep-fat-fried food.

In a descending order, palmitic acid esters were present in Citrullus lanatus (21.20\%), Citrullus vulgaris (2.89\%), Cucumis melo (1.09\%) and Lagenaria siceraria (0.63\%). Palmitic acid is one of the most common saturated fatty acids which can increase unhealthy low density lipoprotein (LDL) cholesterol levels [45]. Being one of the most prevalent saturated fatty acids in body lipids, it could constitute a major risk factor for heart attacks and strokes. Diets high in saturated fatty acids increase the production of acetate fragments in the body which, in turn, leads to an increase in the production of cholesterol. When consumed, saturated fats tend to clump together and form deposits in the body, along with protein and cholesterol. They get lodged in blood cells and organs, leading to many health problems, including obesity, heart diseases and cancers of the breast and colon. However, since the dietary effects of high-fat diet, mainly in saturated fatty acids, have been focused on the reduction of cardiovascular diseases [46,47], obesity-related diseases and, recently, cancer prevention [48], consuming Cucumis melo, Citrullus vulgaris and Lagenaria siceraria having very low levels of saturated fatty acid compared to unsaturated fatty acids and less of Citrullus lanatus having high levels of saturated fatty acids would be of significant benefit. Oluba et al. [49], also, reported that egusi oil could improve serum and liver lipid profiles and offer better protection against resultant lipid peroxides from consumption of high fat diet.

Esters are derived from carboxylic acids. They are mostly formed from the esterification of alcohols with fatty acids during the fermentation process [50] to produce attractive aroma. The esters are presumably the consequence of chemical reactions, possibly catalysed by microbial esterases [51], between microbial acidic and alcoholic metabolites [52]. Methyl tetradecanoate (myristic acid methyl ester) was present in high amount (41.91\%) in Citrullus lanatus. Lauric acid (6.44\%), which is the main antiviral and antibacterial substance found in human breast milk [53], was 
found in Citrullus lanatus. It has inhibitory effect against skin bacteria such as Propioibacterium acne [54], lipid-coated RNA and DNA viruses, numerous pathogenic Gram-positive bacteria and various pathogenic protozoa. n-Hexadecanoic acid was present in Citrullus vulgaris (2.01\%) and Citrullus lanatus (2.80\%) in low quantity. Hexadecanoic acid methyl ester, also known as methyl palmitate, is an aliphatic acid ester reported to cause growth inhibition and apoptosis induction in human gastric cancer cells [55]. It has been found to increase total serum cholesterol than any other fatty acids [56]. Hexadecanoic acid may also act as antimicrobial and antidarrheal agent.

\section{Conclusion}

In conclusion, the lipid profile shows that Cucumis melo, Citrullus vulgaris and Lagenaria siceraria contain high amounts of linoleic acid, an unsaturated fatty acid, which has been known to reduce the risk of cardiovascular diseases. Thus, consumption of these melon seeds will reduce the risk of cardiovascular heart diseases that has become a menace to the society. Therefore, farmers should be encouraged to grow more of these melon seeds so that they can be made available to industries for oil extraction just as soya beans and groundnut seeds are extracted for their oil and sold for human consumption. The consumption of Citrullus lanatus should be reduced as it is found to contain higher saturated fatty acids and esters able to raise blood cholesterol and increase the risk of heart diseases.

\section{Compliance with ethical standards}

\section{Disclosure of conflict of interest}

The authors hereby declare that we do not have any conflict of interest.

\section{References}

[1] Khan MN, Nasiruddin M, Rehman MU and Khurram KW. (2003). A study of chemical composition of Cocos nucifera. (Coconut) water and its usefulness as rehydration fluid. Pakistan Journal of Botany, 35(5), 925-930.

[2] Hussain J, Khan AL, Rehman N, Ullah Z, Hussain ST, Khan F and Shinwari ZK. (2009). Proximate and nutrient analysis of selected medicinal plant species of Pakistan. Pakistan Journal of Nutrition, 8(1), 620-624.

[3] George PM. (2003). Encyclopedia of Foods. Humane Press; Washington, 1, 526.

[4] Ng TJ. (1993). New Opportunities in Cucurbitaceae. In: New Crops. Janick, J. and J.E. Simon (Eds.). Wiley, New York, 538-546.

[5] Oluba OM, Adeyemi O, Ojieh GC, Adebisi KE, Isiosio IO and Aboluwoye CO. (2008). Effect of dietary cholesterol on some serum enzymes. Journal of Medical Sciences, 8(4), 390-394.

[6] Achu MB, Fokou E, Tehiegang C, Fotso M and Tchouanguep FM. (2005). Nutritive value of some Cucurbitaceae oilseeds from different regions in Cameroon. African Journal of Biotechnology, 4(1), 1329-1334.

[7] FAO (1995). Production yearbook, 49, 169.

[8] Van der Vossen HAM, Denton OA and El Tahir IM. (2004). Citrullus lanatus (Thunb.) Matsum and Nakai. In Grubben GJH, Denton OA (eds). Plant Resources of Tropical Africa 2. Vegetables. PROTA

[9] Achigan-Dako EG, Fagbemissi R, Avohou TA, Raymond V, Ousmane NC and Adam A. (2008). Importance and Practices of Egusi crops (Citrillus lanatus (Thunb.) Matsum, \& Nakai, Cucumeropsis mannii Naudin and Lagenaria siceraria (Molina) Standl. cv. 'Aklamkpa') in sociolinguistic areas in Benin. Biotechnology, Agronomy, Society and Environment, 12(4), 393-403.

[10] Gusmini G, Wehner TC and Jarlet RL. (2004). Inheritance of bitter melon seed type in watermelon. Journal of Heredity, 95, 268-270.

[11] Solomon G, Luqman CA and Mariah A. (2010). Investigating bitter melon seed oil as potential biodiesel feedstock. Energies, 3, 601-618.

[12] Onyeike EN and Acheru GN. (2002). Chemical composition of selected Nigerian oil seeds and physicochemical properties of the oil extracts. Food Chemistry, 77, 431-437.

[13] Girgis P and Said F. (1968). Lesser known Nigerian edible oils and fats 1: Characteristics of melon seeds. Journal of Food and Agriculture, 19, 615-616. 
[14] Nwokolo E and Sim JS. (1987). Nutritional assessment of defatted oil and meal of melon (Colocynthis citrullus) and fluted pumpkin (Teilferia occidentalis Hook) by chick assay Journal of the Science of Food and Agriculture, 38, 237- 236.

[15] Ajibola A. (1990). Mechanical Expression of Research. 2nd Edition. Lagos: John and Sons Limited.

[16] Oyolu O. (1977). A qualitative and quantitative study of seed types in 'egusi' (Colocynthis citrullus L.). Tropical Sciences, 19, 51-61.

[17] Dane F, Liu J and Zhang C. (2007). Phylogeography of the bitter apple, Citrullus colocynthis. Genetic Resources and Crop Evolution, 54, 327-336.

[18] Moerman D. (1998) Native American Ethnobotany, Timber press, Oregon, 453-459.

[19] Burkill HM. (1985). Entry for Lasiurus hirsutus (Forssk.) Boiss. [Family-Poaceae]. In: The useful plants of west tropical Africa, 2nd edition. Royal Botanic Gardens, Kew, UK.

[20] Mabalaha MB, Mitei YC and Yoboah SO. (2007). A comparative study of the properties of selected melon seeds oils as potential candidates for development into commercial edible vegetable oil. Journal of the American Oil Chemists' Society, 84, 31-34.

[21] Maynard DN. (2001). Watermelons. Characteristics, production, and marketing. Alexandria, VA: ASHS Press.

[22] Olorode O. (1984). Taxonomy of West African Flowering Plants. Longman Group Ltd, 158.

[23] Badifu GIO. (1993). Food potentials of some unconventional oilseeds grown in Nigeria a brief review. Plant Foods for Human Nutrition, 43, 211-224.

[24] Denton L and Adeniran MO. (1990). Geographic Distribution and performance of the major types of "egusi melon" (Citrullus lanatus) in Nigeria. Nigeria Journal of Horticultural Science 1, 11-13.

[25] Moser BR, Knothe G, Vaughn SF and Isbell TA. (2009). Production and evaluation of biodiesel from field pennycress (Thlaspiar Wense L.) oil, Energy \& Fuels, 23, 4149-4155.

[26] Achinewhu SC. (1984). Amino Acid Composition and Nutritive Value of Protein in Horse Bean (Mucuna uriens).Qual. Plant Plant Foods for Human Nutrition, 34(3), 181-181.

[27] Sawaya NW, Daghir JN and Khan P. (1983). Chemical Characterization and edibility of the oil extracted from Citrullus collocynthis seed. Journal of Food Science, 48, 104-106.

[28] Akoh CC, and Nwosu CV. (1992). Fatty acid composition of melon seed oil lipids and phospholipids. Journal of the American Oil Chemists' Society, 69, 314-316.

[29] Dalziel JM. (1937). Useful plants of West Tropical Africa. Crown Agents, London. 612.

[30] Davies RM. (2010). Engineering properties of three varieties of melon seeds as potentials for development of melon processing machines. Advance Journal of Food Science and Technology, 2(1), 63-66.

[31] Van Wyk BE and Gericke N. (2000). Peoples Plants: A Guide to Useful Plants of Southern Africa. Briza Publications, Arcadia, Pretoria, South Africa, 351.

[32] Yaniv Z, Shabelsky E and Schafferman D. (1999) Colocynth: Potential arid land oilseed from an ancient cucurbit. In Perspectives on New Crops and New Uses, $1^{\text {st }}$ Edition.; Janick, J., Eds.; ASHS Press: Alexandria, VA, USA, 257261.

[33] Uruakpa FO and Aluko RE. (2004) Heat-induced gelation of whole egusi (Colocynthis citrullus) seeds. Food Chemistry, 87, 349-354.

[34] Emmanuel OA and Mudiakeoghene 0. (2008). The use of antioxidants in vegetable oils - A review. African Journal of Biotechnology, 7(25), 4836-4842.

[35] Fashina AB. (1971). The design and development of a melon sheller. Project for B.Sc. Agriculture Hons. University of Ife, Nigeria. 30.

[36] Olaofe O, Adeyemi FO and Adediran GO. (1994). Amino acid and Mineral Composition and Functional Properties of Some Oil Seeds. Journal of Agricultural and Food Chemistry, 42, 878 - 884.

[37] Kinsella JE, Frankel E, German B and Kanner J. (1993). Possible mechanism for the protective role of the antioxidant in wine and plant foods. Food Technology, 47, 85-89. 
[38] Piomelli D. (2000). Arachidonic Acid. Neuropsychopharmacology: The Fifth Generation of Progress. Retrieved 2006-03-03.

[39] Simopoulos AP. (1994). Fatty acids. In Goldberg I, ed, Functional Foods: Designer Foods, Pharmafoods, Nutraceuticals. Chapman \& Hall, New York, 355-392.

[40] Erasmus U. (1999). Fats that Heal, Fats that Kill. Alive Books. Burnaby, British Columbia, Canada.

[41] Imen T, Hdider C, Lenucci MS, Ilahy R, Jebari H and Dalessandro G. (2011). Bioactive compounds and antioxidant activities during fruit ripening of watermelon cultivars of different watermelon cultivars as affected by fruit sampling area. Journal of Food Composition and Analysis, 24, 923-928.

[42] Femenia A, Chen YC, Mulet A and Canelles J. (1995). Chemical composition of bitter and sweet apricot kernels. Journal of Agricultural and Food Chemistry, 43, 356-361.

[43] Shi H and Ho CT. (1994). The flavour of poultry meat. In: Flavour of Meat and Meat Products (Ed. F. Shahidi). Blackie Academic and Professional, Glasgow. 52-69.

[44] Mottram DS. (1998). Flavour formation in meat and meat products: a review. Food Chemistry, 62, 415-424.

[45] Miserey Y. (2010). L'huile de palme, mauvaise graisse omniprésente, Le Figaro, February 9.

[46] Aranceta J and Perez-Rodrigo C. (2012). Recommended dietary reference intakes, nutritional goals and dietary guidelines for fat and fatty acids: A systematic review. British Journal of Nutrition, 107, S8-S22.

[47] Assmann G, Buono P, Daniele A, Della Valle E, Farinaro E, Ferns G, Krogh V, Kromhout D, Masana L, Merino J, et al. (2014). Functional foods and cardiometabolic diseases. International Task Force for Prevention of Cardiometabolic Diseases. Nutrition, Metabolism and Cardiovascular Diseases, 24, 1272-1300.

[48] Berger NA. (2014). Obesity and cancer pathogenesis. Annals of the New York Academy of Sciences, 1311, 57-76.

[49] Oluba OM, Eidangbe GO, Ojieh GC and Idonije BO. (2011). Palm and Egusi melon oils lower serum and liver lipid profile and improve antioxidant activity in rats fed a high fat diet. International Journal of Medicine and Medical Sciences, 3(2), 47-5.

[50] Sluis CVD, Tramper J and Wijffels RH. (2001). Enhancing and accelerating flavour formation by salt tolerant yeasts in Japanese soy-sauce processes. Trends in Food Science and Technology, 12, 322-327.

[51] Eskin NAM. (1990). Biochemistry of Foods (2nd ed.). Academic Press, San Diego, CA. 444.

[52] Leejeerajumnean A, Duckham SC, Owens JD and Ames JM. (2001). Volatile compounds in Bacillus fermented soybeans. Journal of the Science of Food and Agriculture, 81(5), 525-529.

[53] Tayag E and Dayrit CS. (2000). Results analysis of clinical HIV trial with monoglycerides (presentation). The 37th Cocotech Meeting, Chennai, India, July 25, 2000.

[54] Nakatsuji T, Kao MC, Fang JY, Zouboulis CC, Zhang L, Gallo RL and Huang CM. (2009). Antimicrobial Property of Lauric Acid against Propionibacterium acnes: Its Therapeutic Potential for Inflammatory Acne Vulgaris. Journal of Investigative Dermatology, 129(10), 2480-2488.

[55] Yu F, Lian X, Guo H, Mc Guire P, Li R, Wang R. and Yu F. (2005). Isolation and characterization of methyl esters and derivatives from Euphorbia kansui (Euphorbiaceae) and their inhibitory effects on the human SGC-7901 cells. Journal of Pharmacy and Pharmaceutical Sciences, 8(3), 528-535.

[56] Mensick RP, Zock PL, Kester ADM and Katan MB. (2003). Effects of dietary fatty acids and carbohydrates on the ratio of serum total to HDL cholesterol and on serum lipids and apolipoproteins: a meta-analysis of 60 controlled trials. American Journal of Clinical Nutrition, 77(5), 1146-1155.

\section{How to cite this article}

Olajuyigbe AA, Amah GH, Adebawo 00 and Olajuyigbe 00. (2019). Extraction and GC-MS analysis of the fatty acids in commonly consumed melon seed varieties in Nigeria. GSC Biological and Pharmaceutical Sciences, 7(3), 77-92. 